\begin{tabular}{cccc} 
VERSITA & GOSPODARKA & SUROWCAMI & MINERALNYMI \\
\hline \multirow{4}{*}{ Tom 29} & 2013 & Zeszyt 1 \\
& & DOI 10.2478/gospo-2013-0006 &
\end{tabular}

\title{
Study of physico-chemical and mechanical characteristics of consolidated and unconsolidated cemented paste backfills
}

\section{Introduction}

Cemented paste backfill CPB has seen increasing use by mines worldwide, mainly due to its significant cost advantages and the potential for placing the full plant sulphidic tailings in underground stopes (Landriault 2001; Yilmaz 2011). CPB is usually prepared by mixing the tailings, binder, and mixing water to form a composite construction material. After its hardening, the CPB material acts as secondary ground support. The physico-chemical and mineralogical properties of CPB ingredients greatly affect both strength and stability performance (Archibald et al. 1999; Belem et al. 2000; Benzaazoua et al. 2002; 2004; Kesimal et al. 2004; Klein, Simon 2006; Ouellet 2007; Fall, Samb 2008; Yilmaz 2010; Fall et al. 2010; Yilmaz et al. 2011; Cihangir et al. 2012). Uniaxial compressive strength (UCS) is the key index parameter most often used for CPB stability design (Belem, Benzaazoua 2008). The UCS requirements are closely related to the assortment of roles undertaken by CPB. Overall, the target UCS values for CPB vary from 0.25 to $4.35 \mathrm{MPa}$ for a wide range of applications varying from tailings disposal to roof support underground (Hassani, Bois 1992).

CPB design is often based on the evaluated properties of laboratory-prepared backfill material (plastic mould samples). However, experience indicates that it is not easy to ensure that all the physical and mechanical conditions prevailing underground are observed when the CPB sample is prepared, cured, and tested in the laboratory (Servant 2001). Further,

* Department of Applied Sciences, University of Québec at Abitibi-Temiscamingue (UQAT), Québec, Canada; e-mail: Erol.Yilmaz@uqat.ca 
the mechanical and curing properties of in situ CPB material vary noticeably, depending on the methods of preparation, placement, and conditions of the mine environment (le Roux et al. 2005). Previous studies indicate that the UCS magnitudes of in situ CPB material are often 2 to 4 times higher than those obtained from laboratory-prepared samples of equivalent batch mix and curing time (Belem et al. 2002; Cayouette 2003). This discrepancy may be attributed to the fact that the hardening of CPB material cured under an effective field stress increases the rate of strength development and the ultimate strength, as reported lately by a number of authors (Belem et al. 2006; Fourie et al. 2006; Grabinsky, Simms 2006; Helinski et al. 2007; Bussière 2007; Yilmaz et al. 2009, 2012; Ercikdi et al. 2010). Additionally, Revell (2004) has shown that scale effects have an impact on CPB strength gain. To the knowledge of the authors of this text, there is no suitable laboratory apparatus or standardized test procedure for CPB that mimics the field mixing, placement, and curing conditions on a laboratory scale. Moreover, only a few studies showed that consolidation both under self-weight and time-dependent surcharge loading could have a notable effect on the overall performance and quality of CPB materials (le Roux et al. 2005; Yilmaz et al. 2008). In existing documentation, there was a lack of information about the characteristics of CPB cured under applied pressure. Accordingly, an understanding of the effect of curing under stress on CPB performance is required for a more reliable and better quality of backfill design.

The main objective of this study was to evaluate the effects of binder content and curing time on CPB hydromechanical performance, as well as to observe the resulting geochemical properties. To achieve this objective, a new laboratory tool named CUAPS (curing under applied pressure system) was used which allowed for the simulation of the in situ placement and curing conditions of CPB materials (Benzaazoua et al. 2006; Yilmaz et al. 2010). A comparative analysis of the above-mentioned properties of the CPB cured in both plastic moulds and under effective stress was performed using three different binder contents $(3,4.5$, and $7 \mathrm{wt} \%$ ) and curing times $(7,14$, and 28 days).

\section{Material and Method}

\subsection{Characteristics of paste backfill ingredients}

Mill Tailings: the tailings sample used in this study was taken from a Canadian gold mine located in the western part of the province of Quebec. The sample's particle size distribution (PSD) was determined using a Malvern Mastersizer laser diffraction-type particle size analyser (Fig. 1), and fit within a typical range of PSD curves of 11 mine tailings sampled from the underground hard rock mines located in the provinces of Quebec and Ontario, Canada (Ouellet 2007).

Table 1 also shows the main physico-chemical characteristics of the tailings sample. It can be observed that the fines content (less than $20 \mu \mathrm{m}$ ) is $44 \mathrm{wt} \%$ which corresponds 

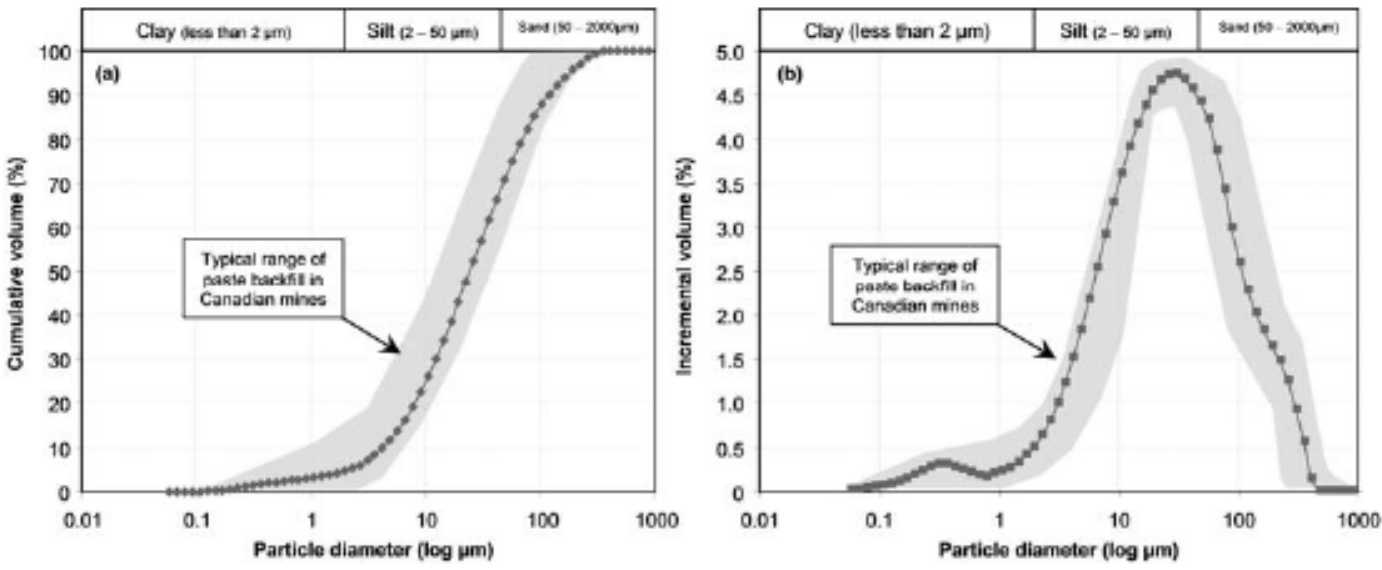

Fig. 1. Particle size distribution curves of the tailings sample used a) cumulative, b) incremental

Rys. 1. Krzywe składu ziarnowego próbek użytych odpadów

a) skumulowana, b) przyrostowa

Main physico-chemical characteristics of the tailings sample used

Charakterystyka podstawowych właściwości fizyko-chemicznych próbek użytych odpadów

\begin{tabular}{|c|c|c|c|c|c|c|c|c|c|c|}
\hline Parameter & $\begin{array}{c}S_{s} \\
\left(\mathrm{~m}^{2} / \mathrm{kg}\right)\end{array}$ & $G_{s}$ & $\begin{array}{c}D_{10} \\
(\mu \mathrm{m})\end{array}$ & $\begin{array}{c}\text { Fines } \\
(<20 \mu \mathrm{m})\end{array}$ & $\begin{array}{c}C_{u} \\
(\mathrm{wt} \%)\end{array}$ & $\begin{array}{c}C_{c} \\
(\mathrm{wt} \%)\end{array}$ & $\begin{array}{c}\mathrm{Al} \\
(\mathrm{wt} \%)\end{array}$ & $\begin{array}{c}\mathrm{Ca} \\
(\mathrm{wt} \%)\end{array}$ & $\begin{array}{c}\mathrm{Fe} \\
(\mathrm{wt} \%)\end{array}$ & $\begin{array}{c}\mathrm{S}_{\text {total }} \\
(\mathrm{wt} \%)\end{array}$ \\
\hline Tailings & 2170 & 3.7 & 4.26 & $44 \mathrm{wt} \%$ & 8 & 1.1 & 2.8 & 0.57 & 27.4 & 20.6 \\
\hline
\end{tabular}

$S_{\mathrm{s}}-$ specific surface,

$D_{10}$ - effective particle diameter.

to medium size tailings, according to Landriault (2001). Tailings are well-graded with a coefficient of uniformity $C_{u}\left(=D_{60} / D_{10}\right)$ of 8 and with a coefficient of curvature $C_{c}\left(=D_{302} / D_{60} \cdot D_{10}\right)$ of 1.1. Based on the Unified Soil Classification System (USCS), the studied mine tailings are classified as low plasticity silt (ML). The specific gravity Gs of the tailings sample that was measured with a Micromeritics $\$$ Accupyc 1330 helium gas pycnometer is 3.7 , reflecting a relatively high content of sulphides.

The chemical composition analyses of metals and total sulphur $\left(\mathrm{S}_{\text {total }}\right)$ were conducted on the tailings sample using a Perkin-Elmerß Model Optima 3100 RL ICP-AES (inductively coupled plasma-atomic emission spectroscope) after complete acid digestion by $\mathrm{HNO}_{3}, \mathrm{Br}_{2}$, $\mathrm{HF}$, and $\mathrm{HCl}$. Dilute $\mathrm{HCl}$ was used to extract sulfates, and the solution obtained was analyzed by ICP-AES. From the chemical composition analysis carried out on the tailings sample, 
it can be observed that the contents of iron $\mathrm{Fe}$, sulphur $\mathrm{S}$, aluminium $\mathrm{Al}$, and calcium $\mathrm{Ca}$ were $27.4 \mathrm{wt} \%, 20.6 \mathrm{wt} \%, 2.8 \mathrm{wt} \%$, and $0.57 \mathrm{wt} \%$, respectively.

Binding agent: the binder used for the preparation of CPB samples is a blend of ordinary Portland cement or Type I (PCI) and ground, granulated blast furnace slag (Slag). The blending ratio of PCI to Slag is 20/80. Three different binder proportions of $3,4.5$, and $7 \mathrm{wt} \%$ were chosen to evaluate the effect of curing conditions on the UCS performance of CPB samples. Proportions were calculated on the basis of weight relative to the total dry tailings. The chemical composition analyses were also conducted on the studied binder samples using ICP-AES method, as explained in the previous section. Table 2 shows the main chemical composition and physical properties of binders.

Mixing water: two types of water namely as-received tailings, pore water, and tap mixing water were chemically analyzed using ICP-AES method. Table 3 summarizes the results of the chemical and geochemical analyses. It can be observed that the pore water is highly aggressive in terms of sulphate content $\left(\mathrm{SO}_{42}\right.$ - content around $\left.4880 \mathrm{ppm}\right)$ but also contains calcium (Ca content about $560 \mathrm{ppm}$ ). While $\mathrm{Ca}$ comes from the lime added during ore treatment, sulphates can come from the cyanide elimination process (tailings are treated before backfilling) and those produced from sulphide reactivity (Benzaazoua et al. 2004). Additionally, the values in terms of $\mathrm{pH}, \mathrm{Eh}$ (redox potential), and EC(electrical conductivity) of pore and tap waters were $9.41,0.147$ volt, and $7.42 \mathrm{mS} / \mathrm{cm}$; and $7.82,0.431$ volt, and

TABLE 2

Chemical composition and some physical properties of the binders used

TABELA 2

Skład chemiczny i właściwości fizyczne niektórych ẇywanych spoiw

\begin{tabular}{|l|c|c|c|c|c|c|c|c|c|c|}
\hline Parameter & $\begin{array}{c}S_{s} \\
\left(\mathrm{~m}^{2} / \mathrm{kg}\right)\end{array}$ & $G_{s}$ & $\begin{array}{c}\mathrm{Al}_{2} \mathrm{O}_{3} \\
(\mathrm{wt} \%)\end{array}$ & $\begin{array}{c}\mathrm{CaO} \\
(\mathrm{wt} \%)\end{array}$ & $\begin{array}{c}\mathrm{Fe}_{2} \mathrm{O}_{3} \\
(\mathrm{wt} \%)\end{array}$ & $\begin{array}{c}\mathrm{K}_{2} \mathrm{O} \\
(\mathrm{wt} \%)\end{array}$ & $\begin{array}{c}\mathrm{MgO} \\
(\mathrm{wt} \%)\end{array}$ & $\begin{array}{c}\mathrm{Na}_{2} \mathrm{O} \\
(\mathrm{wt} \%)\end{array}$ & $\begin{array}{c}\mathrm{SO}_{3} \\
(\mathrm{wt} \%)\end{array}$ & $\begin{array}{c}\mathrm{SiO}_{2} \\
(\mathrm{wt} \%)\end{array}$ \\
\hline PCI & 1580 & 3.1 & 4.86 & 65.76 & 2.44 & 0.83 & 2.21 & 2.11 & 3.67 & 19.51 \\
\hline Slag & 3540 & 2.8 & 10.24 & 31.41 & 0.55 & 0.51 & 11.3 & 2.01 & 3.27 & 36.22 \\
\hline PCI-Slag & 2840 & 2.9 & 4.26 & 42.82 & 0.64 & 0.55 & 6.19 & 2.03 & 3.35 & 30.91 \\
\hline
\end{tabular}

TABLE 3

Chemical and geochemical analysis results of pore and tap waters used as mixing water

TABELA 3

Chemiczne i geochemiczne wyniki analizy porów i odcieków wody wykorzystywanych jako woda zasobowa

\begin{tabular}{|c|c|c|c|c|c|c|c|c|c|c|}
\hline $\begin{array}{c}\text { Parameter/ } \\
\text { /element }\end{array}$ & $\begin{array}{c}E C \\
(\mathrm{mS} / \mathrm{cm})\end{array}$ & $\mathrm{pH}$ & $\begin{array}{c}\mathrm{Eh} \\
(\mathrm{v})\end{array}$ & $\begin{array}{c}\mathrm{SO}_{4}^{2} \\
(\mathrm{ppm})\end{array}$ & $\begin{array}{c}\mathrm{Si} \\
(\mathrm{ppm})\end{array}$ & $\begin{array}{c}\mathrm{Mg} \\
(\mathrm{ppm})\end{array}$ & $\begin{array}{c}\mathrm{Al} \\
(\mathrm{wt} \%)\end{array}$ & $\begin{array}{c}\mathrm{Ca} \\
(\mathrm{ppm})\end{array}$ & $\begin{array}{c}\mathrm{Cu} \\
(\mathrm{ppm})\end{array}$ & $\begin{array}{c}\mathrm{Fe} \\
(\mathrm{wt} \%)\end{array}$ \\
\hline Pore water & 7.42 & 9.4 & 0.147 & 4883 & 0.891 & 1.83 & 0.212 & 559 & 0.286 & 0.011 \\
\hline Tap water & 0.274 & 7.8 & 0.431 & 138 & 0.901 & 2.27 & 0.01 & 40.9 & 0.835 & 0.066 \\
\hline
\end{tabular}


$0.274 \mathrm{mS} / \mathrm{cm}$, respectively. The relatively high value of $\mathrm{EC}$ within the pore water of as-received tailings indicates the presence of many dissolved conducting ions.

\subsection{Experimental program}

Experimental apparatus: The CUAPS (Curing Under Applied Pressure System) was developed for simulating field placement and curing conditions of laboratory-prepared CPB materials. The CUAPS apparatus has been described previously by Benzaazoua et al. (2006) and Yilmaz et al. (2010). The CUAPS allows the operator to estimate the more realistic UCS values of the CPB materials cured under constant or variable pressure up to $400 \mathrm{kPa}$. The operating principle of CUAPS is that CPB is one-dimensionally consolidated by effective stress over time. A Polycarbonate Perspex tube in the CUAPS apparatus forms a component highly resistant to volume change after a series of stresses are applied. Following an increase in effective stress, excess pore water within CPB is expulsed through a drainage port located at the bottom of the CUAPS. During curing, drainage water is collected in order to calculate the drainage rate and to analyze the chemical composition for the different recipes.

Backfill sample preparation: the CPB ingredients (i.e. tailings, cement, and water) were thoroughly mixed using a double spiral mixer for about 7 minutes. Right after mixing, the measured slump of all mixtures was set to approximately 7 inches by adding more or less mixing water. The slump test was conducted according to the ASTM C143 standard. The initial water content $w_{g}$ for all CPB samples was kept constant at $28.2 \mathrm{wt} \%$.

Table 4 lists the initial bulk properties of each CPB batch mix. These values represent volumetric binder content $B_{v}$, solids mass concentration $C_{w}$, volumetric solids concentration $C_{v}$, water-to-cement ratio $w / c$, specific gravity $G_{s}$, void ratio $e$, wet density $\rho$, dry density $\rho_{d}$, and volumetric water content $\theta$. It can be observed from Table 4 that the $w / c$ ratios decrease from 9.68 to 4.31 when the amount of binder added to the CPB batch is increased from 3 to $7 \mathrm{wt} \%$. Also, $\rho_{d}$ value was 1810,1800 , and $1790 \mathrm{~kg} / \mathrm{m}^{2}$ for $3,4.5$, and $7 \mathrm{wt} \%$ binder contents, respectively.

TABLE 4

Initial bulk properties of different paste backfill materials prepared for a given batch mix

TABELA 4

Właściwości początkowe (pierwotne) różnych materiałów sypkich do zawiesiny przygotowane dla danej partii mieszanki (zawiesiny)

\begin{tabular}{|c|c|c|c|c|c|c|c|c|c|c|}
\hline Parameter & $\begin{array}{c}\rho \\
\left(\mathrm{kg} / \mathrm{m}^{2}\right)\end{array}$ & $\begin{array}{c}B_{v} \\
(\mathrm{wt} \%)\end{array}$ & $\begin{array}{c}C_{w} \\
(\mathrm{wt} \%)\end{array}$ & $\begin{array}{c}C_{v} \\
(\mathrm{wt} \%)\end{array}$ & $G_{s}$ & $w / c$ & $e$ & $\begin{array}{c}\rho_{d} \\
\left(\mathrm{~kg} / \mathrm{m}^{2}\right)\end{array}$ & $\begin{array}{c}S_{r} \\
(\mathrm{wt} \%)\end{array}$ & $\theta$ \\
\hline $3.0 \mathrm{wt} \%$ & 2320 & 3.8 & 78 & 49.1 & 3.68 & 9.68 & 1.04 & 1810 & 100 & 0.5 \\
\hline $4.5 \mathrm{wt} \%$ & 2310 & 5.7 & 78 & 49.2 & 3.66 & 6.55 & 1.03 & 1800 & 100 & 0.5 \\
\hline $7.0 \mathrm{wt} \%$ & 2300 & 8.8 & 78 & 49.3 & 3.64 & 4.31 & 1.03 & 1790 & 100 & 0.5 \\
\hline
\end{tabular}



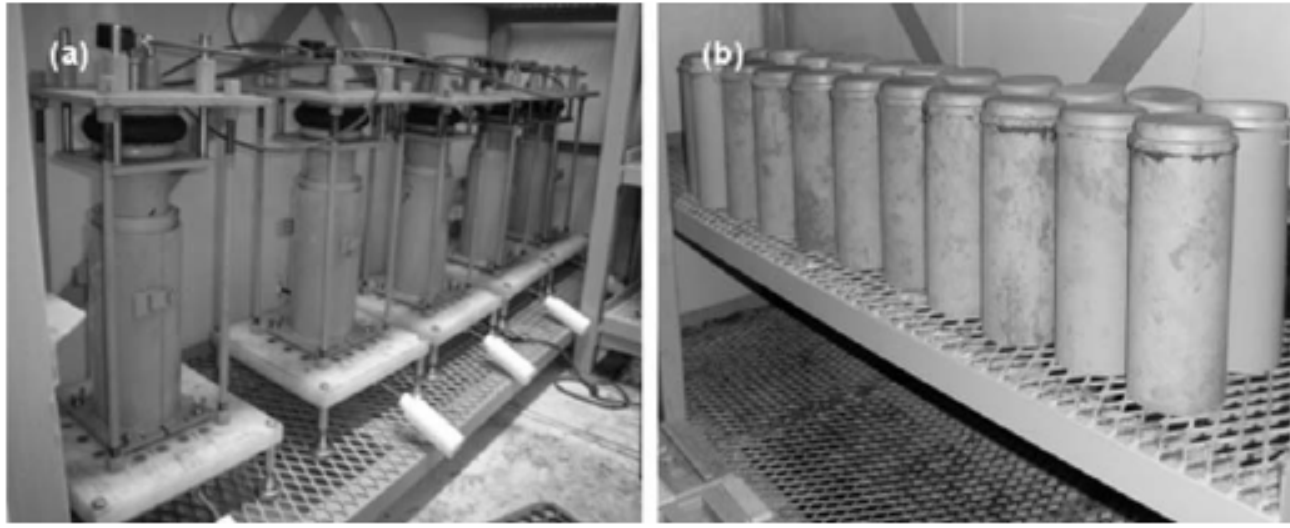

Fig. 2. Photos of (a) CUAPS samples and (b) plastic mould samples curing in a humidity chamber

Rys. 2. Zdjęcia: a) próbli CUAPS, b) próbki z formy ze sztucznego tworzywa w komorze wilgotnościowej

Immediately after mixing, the prepared paste materials were poured into both plastic moulds and transparent polycarbonate round tubes. Tubes and moulds have a shape factor of 2 that corresponds to the height-to-diameter ratio. The CPB samples were then sealed and stored in a damp room maintained at $\sim 80 \%$ relative humidity and $24^{\circ} \mathrm{C}\left( \pm 2^{\circ} \mathrm{C}\right)$ in order to mimic curing conditions similar to those observed in the underground stopes of the mine under study. Fig. 2 shows CUAPS-consolidated CPB and plastic mould-unconsolidated CPB samples being cured in a controlled-humidity chamber.

One-dimensional consolidation tests: as part of the present study, one-dimensional consolidation tests inspired by ASTMD 2435 and D 4186 standard operating procedures were carried out. CPB samples were consolidated using the CUAPS which allows a pressure range of $0-500 \mathrm{kPa}$. Before running the tests, a seating stress of $15 \mathrm{kPa}$ was applied to provide contact between the sample and loading platen. Then, an example stress sequence of 0.5 , $25,50,100,200$, and $400 \mathrm{kPa}$ based on a load increment ratio LIR of 1 was applied to the $\mathrm{CPB}$, and the axial deformations during each stress increment were measured with linear displacement variable transducers through a HOBO U12-4 data logger at a time interval of $0,2,4,6,8$, and $10 \mathrm{~h}$. All stresses were incrementally applied during the first day of curing and unloaded down to $0.5 \mathrm{kPa}$ after a desirable curing time.

Unconfined compression tests: A total of 36 CPB samples, 9 CUAPS-consolidated samples, and 27 mould-unconsolidated samples were cured for uniaxial compressive strength (UCS) tests after periods of 7, 14, and 28 days. After curing, all CPB samples were subjected to the UCS tests according to ASTM C39 using a computer controlled MTS 10/GL press which has a nominal loading capacity of $50 \mathrm{kN}$ and a displacement speed of $1 \mathrm{~mm} / \mathrm{min}$. The UCS magnitude of each sample was recorded (peak or ultimate stress) along with the elasticity modulus of deformation. For a given binder proportion and curing time, only one-test was done for the CUAPS-consolidated samples, whereas an average of three tests were performed for mould-unconsolidated samples. 
Bulk properties determination: after UCS testing, the calculated and/or measured CPB geotechnical index (bulk properties) parameters were determined as follows: gravimetric water content $w(\%)$, solids specific gravity $G_{s}$, degree of saturation $S_{r}(\%)$, void ratio $e$ (or porosity $n)$, volumetric water content $\theta$, dry density $\rho\left(\mathrm{g} / \mathrm{cm}^{3}\right)$, solid concentration $C_{w}(\%)$, and specific surface area $S_{s}\left(\mathrm{~m}^{2} / \mathrm{kg}\right)$. The $S \mathrm{~s}$ parameter, based on the BET (Brunauer, Emmett and Teller) method, was evaluated by nitrogen $\mathrm{N}_{2}$ isotherm adsorption using a Micromeritics $($ surface analyzer model Gemini III.

Chemical and geochemical analysis: during the one-dimensional consolidation test, a quantity of water was collected from each CUAPS-consolidated CPB sample at a specific time interval. After the acidifying process, analysis of the chemical composition of the collected water was carried out using a Perkin-Elmer ICP-AES (Optima 3100 RL). In addition, the $\mathrm{pH}$, redox potential (Eh), and electrical conductivity (EC) parameters were also measured using a Benchtop $\mathrm{pH} / \mathrm{ISE}$ meter Orion Model 920A coupled with a Thermo Orion Triode combination electrode (Pt-Ag-AgCl).

\section{Results}

\subsection{Drainage water of consolidated CPB samples}

Fig. 3 shows the evolution of cumulative drainage water $W_{d}$ versus elapsed time for CUAPS-consolidated CPB samples prepared with a binder content of $3,4.5$, and $7 \mathrm{wt} \%$ as a function of elapsed time (7, 14 and 28 days of curing). It can be observed from Fig. 3 that the $W_{d}$ parameter is greatly affected by the hardening process, depending on the amount of binder added to the CPB. The drainage rate decreases with increases in each binder content. For a 8-day curing time, the volume of drainage water for CPB with 3, 4.5, and $7 \mathrm{wt} \%$ binder was $19.6 \mathrm{wt} \%(253.5 \mathrm{~mL}), 18.8 \mathrm{wt} \%(242.7 \mathrm{~mL})$, and $17.1 \mathrm{wt} \%(217.8 \mathrm{~mL})$, respectively. Also, the pressure varying from 0.5 to $400 \mathrm{kPa}$ played a key role in the volume of water collected from the samples. Overall, a pressure of 100,200 , and $400 \mathrm{kPa}$ corresponding to an elapsed time varying between 120 and 600 minutes induced a significant gap in the magnitude of $W_{d}$. However, a lower pressure of $0.5,25$, and $50 \mathrm{kPa}$ did not have a big influence on the water collection even at early curing times (up to 7 days).

\subsection{Vertical strain of consolidated CPB samples}

Fig. 4 shows the evolution of the vertical strain $\varepsilon_{v}\left(=\Delta \mathrm{H} \cdot 100 / \mathrm{H}_{0}\right)$ of CUAPS-consolidated CPB samples cured under variable pressures as a function of binder content $(3,4.5$, and $7 \mathrm{wt} \%)$. For a given applied pressure, Fig. 4 shows that the total $\varepsilon_{v}$ observed from CPB samples containing $3 \mathrm{wt} \%$ binder is slightly greater than those observed from CPB samples containing the 4.5 and $7 \mathrm{wt} \%$ binder content. For pressure greater than $200 \mathrm{kPa}$, the settlement behaviour is relatively similar. For a binder content of $3,4.5$, and $7 \mathrm{wt} \%$, 

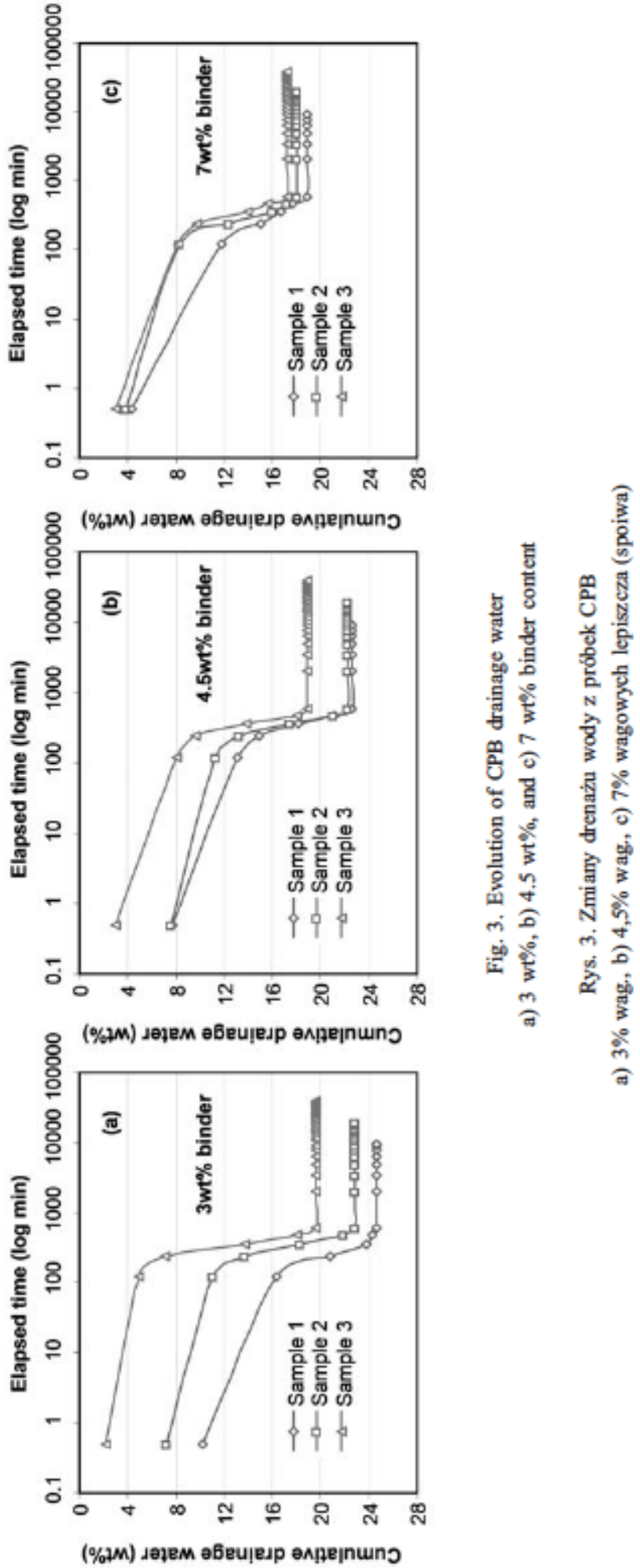

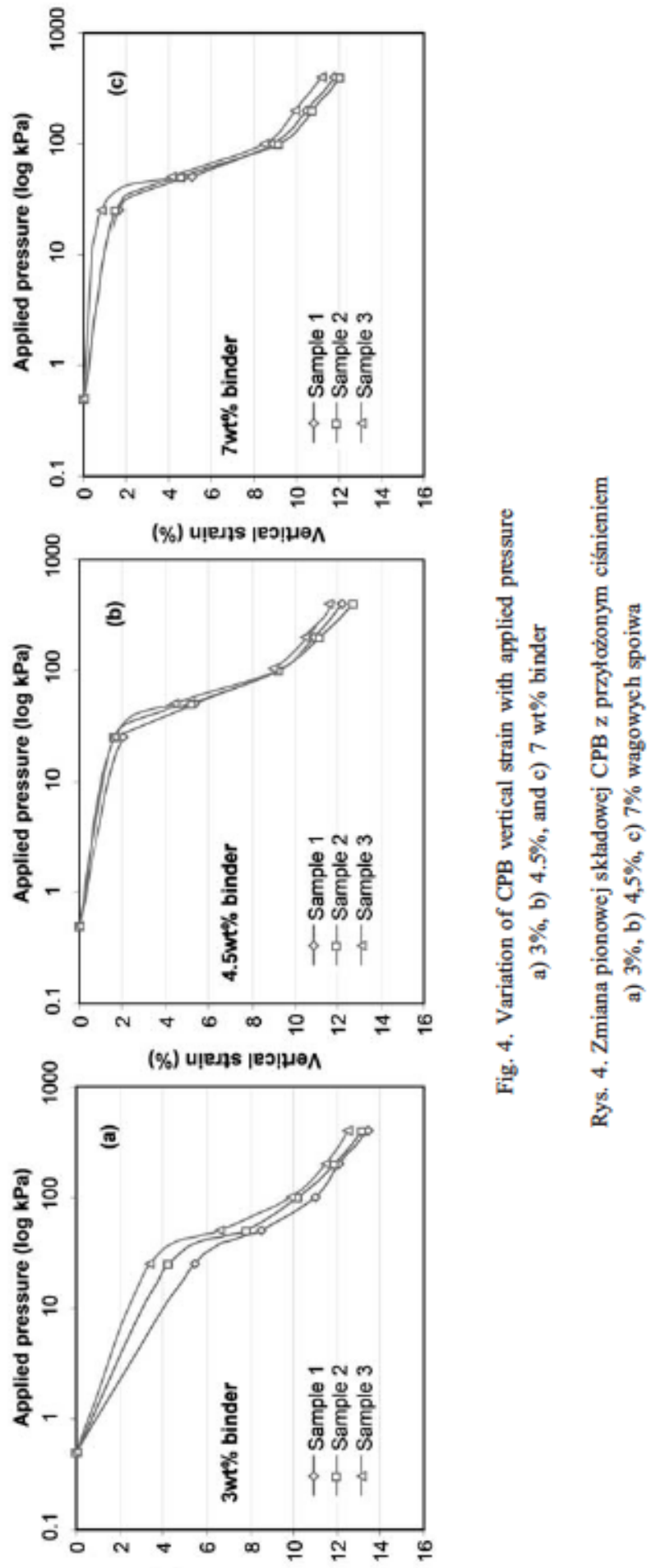

(\%) u|еns |еэน०ᄉ 
the observed $\varepsilon_{v}$ value varies from 12.5 to $13.4 \%$, from 12.2 to $13.3 \%$, and from 11.2 to 12.1 for samples 1,2 , and 3 , respectively. The shape of the curves is different particularly for pressure less than $200 \mathrm{kPa}$. As the amount of binder added to CPB material increases, the $\varepsilon_{v}$ value decreases mainly because of binder hydration during the first day.

\subsection{Characterization of CPB mechanical strength}

Fig. 5 shows the difference in terms of strength development between CUAPS-consolidated CPB samples and plastic mould-unconsolidated CPB samples as a function of binder content and curing time. Strength proportionally increases with binder content as expected. Generally, the CUAPS-consolidated CPB samples systematically produce higher mechanical strength (higher UCS value) than mould-unconsolidated samples, regardless of the curing time. This difference is $57.9 \%, 64.3 \%$, and $58.2 \%$ for $3 \mathrm{wt} \%$ binder content; $52.3 \%, 54.3 \%$, and $51.8 \%$ for $4.5 \mathrm{wt} \%$ binder content; and $50.5 \%, 27.1 \%$, and $19.8 \%$ for $7 \mathrm{wt} \%$ binder content (Fig. 5a, b, c). The highest UCS gap was obtained for CPB with $3 \mathrm{wt} \%$ binder
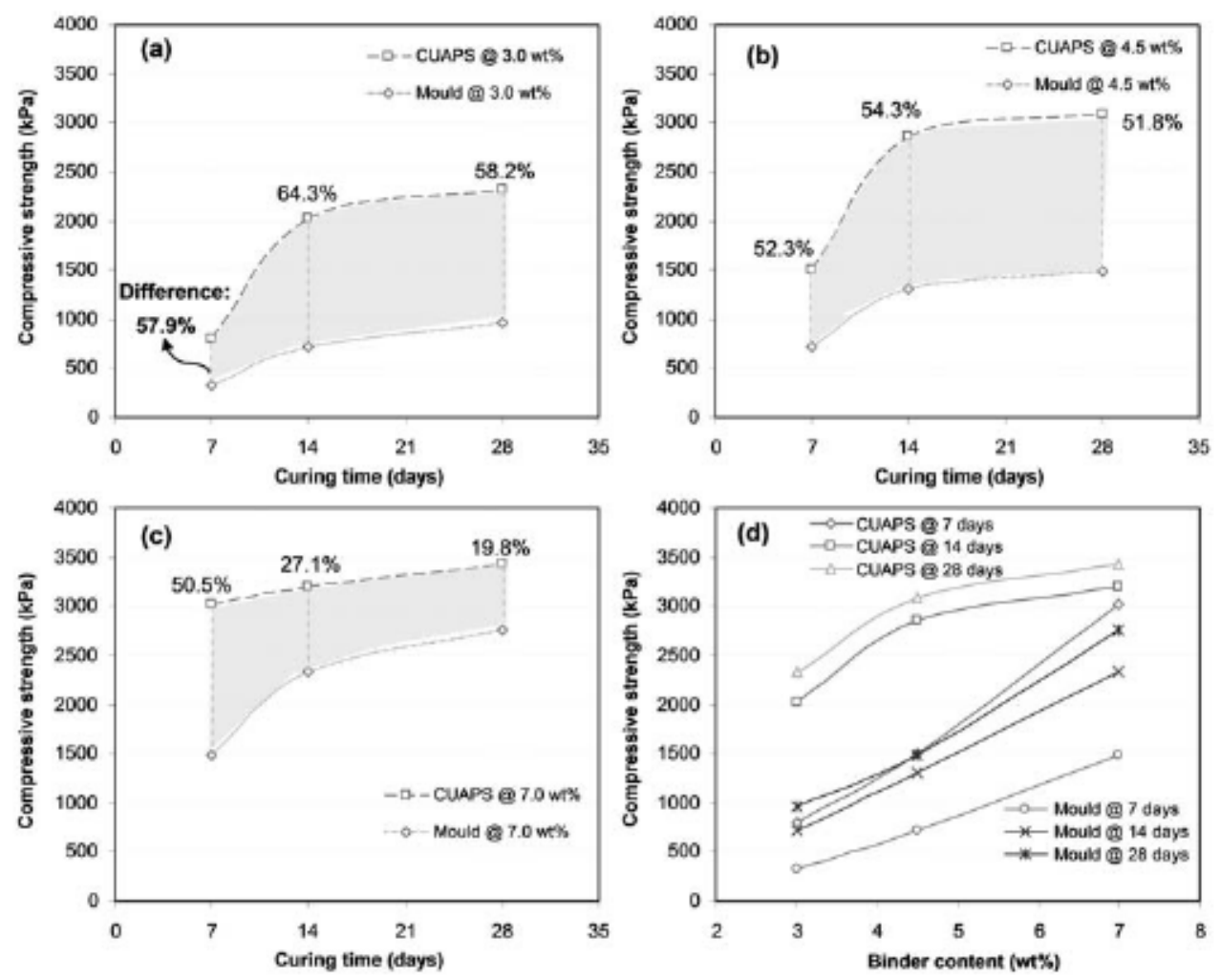

Fig. 5. Comparison of CPB strength

a) $3 \mathrm{wt} \%$, b) $4.5 \mathrm{wt} \%$, c) $7 \mathrm{wt} \%$, and d) mixed results

Rys. 5. Porównanie siły CPB

a) $3 \%$, b) $4,5 \%$, c) $7 \%$ wag., d) różne wyniki 
content. One of the probable reasons for such a high UCS variation could be the high drainage of excess water from these mixes during consolidation which reduces the resultant porosity and permeability. During the drainage, the stiffness of consolidated samples increases as a function of increasing density.

Another reason is that the hardening of CPB materials being cured under different effective stresses greatly contributes to the strength development of backfill. If a series of effective stresses is applied just before the commencement of curing which contributes to $\mathrm{CPB}$ hardening, as is being practiced in the present investigation, the rate of strength increase (short-term property), ultimate strength (mid-term property), and durability (long-term property) will be greater compared to the application of pressure after the completion of hydration. It has been experimentally shown from Belem et al. (2002) and Yilmaz et al. $(2008,2009)$ that the primary bonds in cement in CPB may be broken due to hydrates damage caused by the applied pressure (overloading) in early stages of strength development, which thus reduces the strength and stiffness.

\subsection{Characterization of CPB geotechnical index parameters}

Fig. 6 shows the variation of the geotechnical index parameters of CUAPS-consolidated and plastic mould-unconsolidated CPB samples containing a binder content of 3, 4.5, and $7 \mathrm{wt} \%$ as a function of curing time. The measured geotechnical index parameters are as follows: the gravimetric water content $w_{g}(\%)$, dry density $\rho_{d}\left(\mathrm{~g} / \mathrm{cm}^{3}\right)$, specific surface $S_{s}\left(\mathrm{~m}^{2} / \mathrm{kg}\right)$, degree of saturation $S_{r}(\%)$, and void ratio $e$. There is a notable variation in water content, dry density, and void ratio. The CUAPS samples have a $w_{g}$ value varying between $18.8-11.2 \mathrm{wt} \%$, a $\rho_{d}$ value varying between $2.13-2.08 \mathrm{~g} / \mathrm{cm}^{3}$, and a void ratio $e$ value varying between $0.7-0.57$; while mould samples have a $w_{g}$ value varying between $25.2-17 \%$, a $\rho_{d}$ value varying between $1.85-1.87 \mathrm{~g} / \mathrm{cm}^{3}$, and a void ratio $e$ value varying between $0.95-0.71$. In addition, the final water content $w_{g}$ and degree of saturation $S_{r}$ are highly influenced by the drainage ability of CPB. The highest binder content ( $7 \mathrm{wt} \%)$ exhibits the lowest $w_{g}$ and $S_{r}$. This could basically be explained by the different initial $w / c$ ratios (Table 4) and the amounts of water required for binder hydration.

It was shown by several authors (Belem et al. 2006; Benzaazoua et al. 2004; Yilmaz et al. 2008) that drainage of the excess water existing within the CPB sample contributes to a better hardening process (water trapped during the cement hydration or hydrated phase precipitation as gypsum) for CPB material and, consequently, the reduction of the total void ratio of backfilling. The rate of water drainage is also significantly affected by the settling (i.e. improved consolidation and/or density increase) of the CPB sample being cured under a series of pressure levels during the first step of curing, thus demonstrating higher strengths. Specific surface area $S_{s}$ is also closely related to the hardening phase formation during curing, and the ultimate mechanical strength. The higher the binder content used, the greater the overall $S_{s}$ value of the CPB due to hydrate growth. The UCS values increase with the increasing $S_{s}$ values for a given binder content. Overall, one can say from these tests that the 

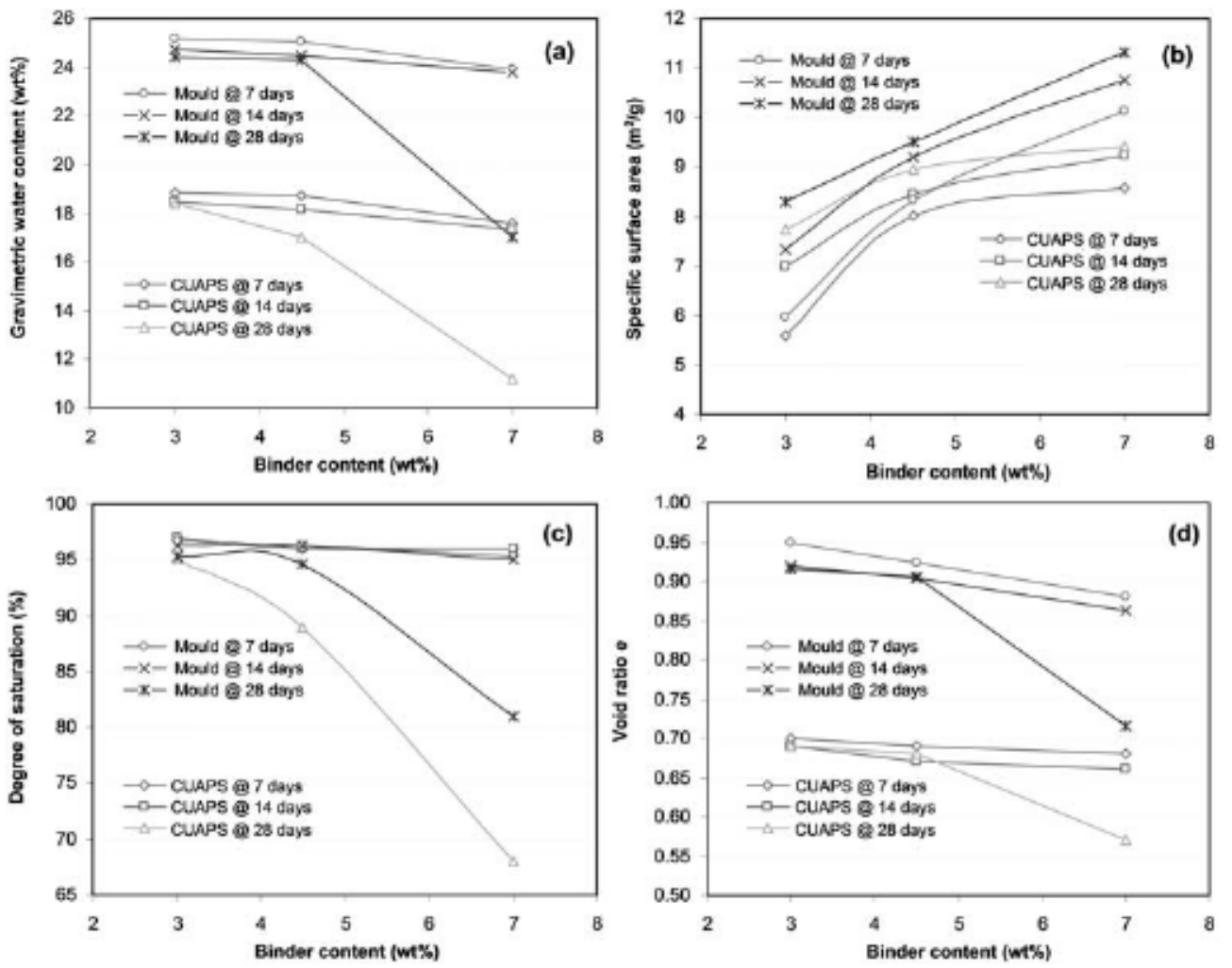

Fig. 6. Evolution of $\mathrm{CPB}$ geotechnical index parameters as a function of binder content and curing time

Rys. 6. Zmiana CPB parametrów indeksu geotechnicznego

w zależności od zawartości spoiwa i czasu utwardzania

CUAPS-consolidated samples give lower $w_{g}$ and $S_{r}$, and higher UCS than those obtained using plastic moulds due to the variation in the initial void ratio $e_{0}$ and the influence of time-dependent consolidation settlement.

\section{Discussion}

\subsection{Correlation between the mechanical strengths}

From the compression test results shown in Fig. 7, it seems that a strong correlation exists between the UCS obtained from CUAPS-consolidated samples (UCS $\left.S_{\mathrm{CUAPS}}\right)$ and the UCS obtained from mould samples (UCS $S_{\text {mould }}$ ). After normalizing the UCS values for binder content and curing time, it was possible to observe the correlation between the two sets of UCS data. This normalization consisted of multiplying each UCS variable by the binder content/curing time ratio (UCS $\cdot B_{w \% / t}$ ). 


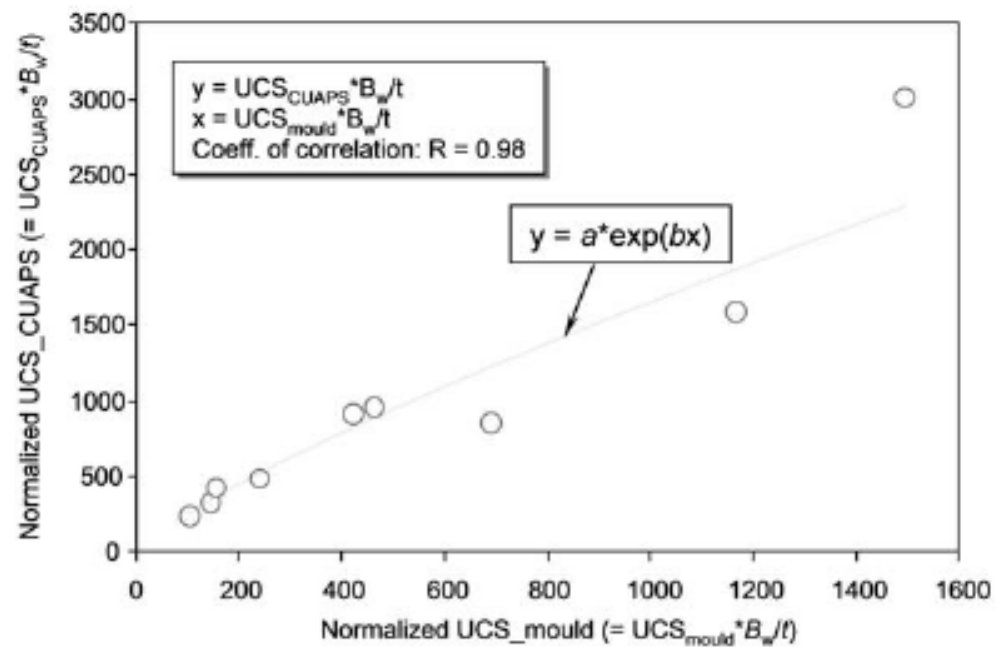

Fig. 7. Correlation between UCS $\mathrm{CUNPS}_{\text {and }}$ UCS $\mathrm{S}_{\text {mould }}$ based on binder content and curing time

Rys. 7. Korelacja pomiędzy UCS

Fig. 7 shows the relationship between $U C S_{\text {CUAPS }}$ and $U C S_{\text {mould. }}$. It should be noted that at first approximation, it appears this relationship could be well-described by an exponential function such as $y=a \cdot \exp (b \cdot x)$. Indeed, a coefficient of correlation $R=0.98$ was obtained, thus indicating the strong relationship existing between the two types of UCS variables. The exponential relationship describing the correlation between these two types of variables (UCS CUAPS $\left._{\text {, }} U C S_{\text {mould }}\right)$ is as follows:

$$
U_{C S} S_{C U P S} \cdot\left(\frac{B_{w \%}}{t}\right)=360952 \cdot \exp \left(0.001399 \cdot\left[U_{\text {mould }} \cdot \frac{B_{w \%}}{t}\right]\right)
$$

where:

$$
\begin{aligned}
& B_{\mathrm{w} \%}-\text { binder content (wt\%), } \\
& t \quad-\text { curing time (day), }
\end{aligned}
$$

UCS values are in $\mathrm{kPa}$.

Finally, the predictive CUAPS-consolidated backfill samples equation from known mould-unconsolidated backfill samples is given as follows:

$$
U C S_{C U A P S} \cdot\left(\frac{360952 \cdot t}{B_{w \%}}\right) \cdot \exp \left(U C S_{m o u l d} \cdot \frac{0001399 \cdot B_{w \%}}{t}\right)
$$

The above equations are specific to the CPB tested and to the loading sequence applied in this study (see the section on one-dimensional consolidation tests). However, ongoing 
research on the influence of different pressure loading rates on CPB consolidation characteristics, and consequently on its strength development, is underway. After these tests, it would be possible to develop a more general equation that could be used to improve prediction of CPB strength.

\subsection{Chemical analys is of drainage water}

Table 5 shows the variation in the chemical analysis of drainage water obtained from CUAPS-consolidated CPB samples during 1-D consolidation tests. Overall, the calcium $\mathrm{Ca}$, silicon $\mathrm{Si}$, and sulphates $\mathrm{SO}_{4}{ }^{2-}$ concentrations of $\mathrm{CPB}$ samples containing 3, 4.5, and $7 \mathrm{wt} \%$ binder content decreased with increasing curing time. The variation in terms of chemical composition can be explained by the different chemical compositions of both binder and tailings pore water and tap water (see Table 3) used for the CPB mixture, relating to the hydration and precipitation process at early stages. However, the variation is also due to the fact that the denser the cementitious matrix, the more this later acts as a filter of colloidal species from the pore waters. It can be interpreted from Table 5 that for a given binder content, calcium $\mathrm{Ca}$ concentration is higher at early ages (7 days) and begins to reduce appreciably when the curing time is increased to 28 days.

The reason for this phenomenon can be explained by the dissolution of Ca-bearing mineral within the cement during early hydration stages. At this stage, $\mathrm{Ca}$ remains trapped in porous media. The dissolved $\mathrm{Ca}$ is expulsed from the sample along with drainage water as a function of pressure. In a similar manner, $\mathrm{Si}$ concentration is reduced with increased

TABLE 5

Chemical composition of water collected from CUAPS-consolidated CPB samples

TABELA 5

Skład chemiczny wody pobranej z CUAPS konsolidowanych próbkami CPB

\begin{tabular}{|c|c|c|c|c|c|c|c|}
\hline $\begin{array}{c}\text { Binder } \\
\text { content }\end{array}$ & $\begin{array}{c}\text { Curing } \\
\text { (day) }\end{array}$ & $\begin{array}{c}\mathrm{Al} \\
(\mathrm{ppm})\end{array}$ & $\begin{array}{c}\mathrm{Ca} \\
(\mathrm{ppm})\end{array}$ & $\begin{array}{c}\mathrm{Fe} \\
(\mathrm{ppm})\end{array}$ & $\begin{array}{c}\mathrm{Mg} \\
(\mathrm{ppm})\end{array}$ & $\begin{array}{c}\mathrm{Si} \\
(\mathrm{ppm}\end{array}$ & $\begin{array}{c}\mathrm{SO}_{4}{ }^{2-} \\
(\mathrm{ppm})\end{array}$ \\
\hline \multirow{3}{*}{$3.0 \mathrm{wt} \%$} & 7 & 0.03 & 436 & 0.07 & 0.08 & 13.3 & 6692 \\
\cline { 2 - 8 } & 14 & 0.02 & 429 & 0.13 & 0.04 & 12.5 & 6411 \\
\cline { 2 - 8 } & 28 & 0.03 & 284 & 0.15 & 0.05 & 11.7 & 4945 \\
\hline \multirow{3}{*}{$4.5 \mathrm{wt} \%$} & 7 & 0.01 & 420 & 0.06 & 0.02 & 15.0 & 6390 \\
\cline { 2 - 8 } & 14 & 0.02 & 302 & 0.12 & 0.05 & 14.0 & 6100 \\
\hline \multirow{3}{*}{$7.0 \mathrm{wt} \%$} & 28 & 0.03 & 247 & 0.17 & 0.01 & 13.5 & 3056 \\
\cline { 2 - 8 } & 7 & 0.01 & 412 & 0.08 & 0.02 & 28.0 & 6279 \\
\cline { 2 - 8 } & 28 & 0.03 & 251 & 0.13 & 0.78 & 27.5 & 5572 \\
\hline
\end{tabular}


curing time, but at lower rates than $\mathrm{Ca}$ due to the fact that $\mathrm{Si}$ occurs as gel phases in solid form. One can also say that sulphate concentration is relatively higher $(6692,6390$, and $6279 \mathrm{ppm}$ for $3,4.5$, and $7 \mathrm{wt} \%$ binder respectively at 7 days of curing) than the concentration observed from the tailings pore water $(4883 \mathrm{ppm}$, also Table 3$)$. This means that sulphate concentration increases during mixing at early curing ages due to aeration contributing to sulphide oxidation by oxygen intake. Also, the sulphates can come from the sulphated mineral dissolution from the binder.

\subsection{Geochemical analysis of drainage water}

Fig. 8 shows a variation in geochemical analyses of water collected from the CUAPS-consolidated CPB samples containing a binder content of 3, 4.5 , and $7 \mathrm{wt} \%$. The measured parameters are $\mathrm{pH}$, redox potential, $(\mathrm{Eh})$ and electrical conductivity (EC).
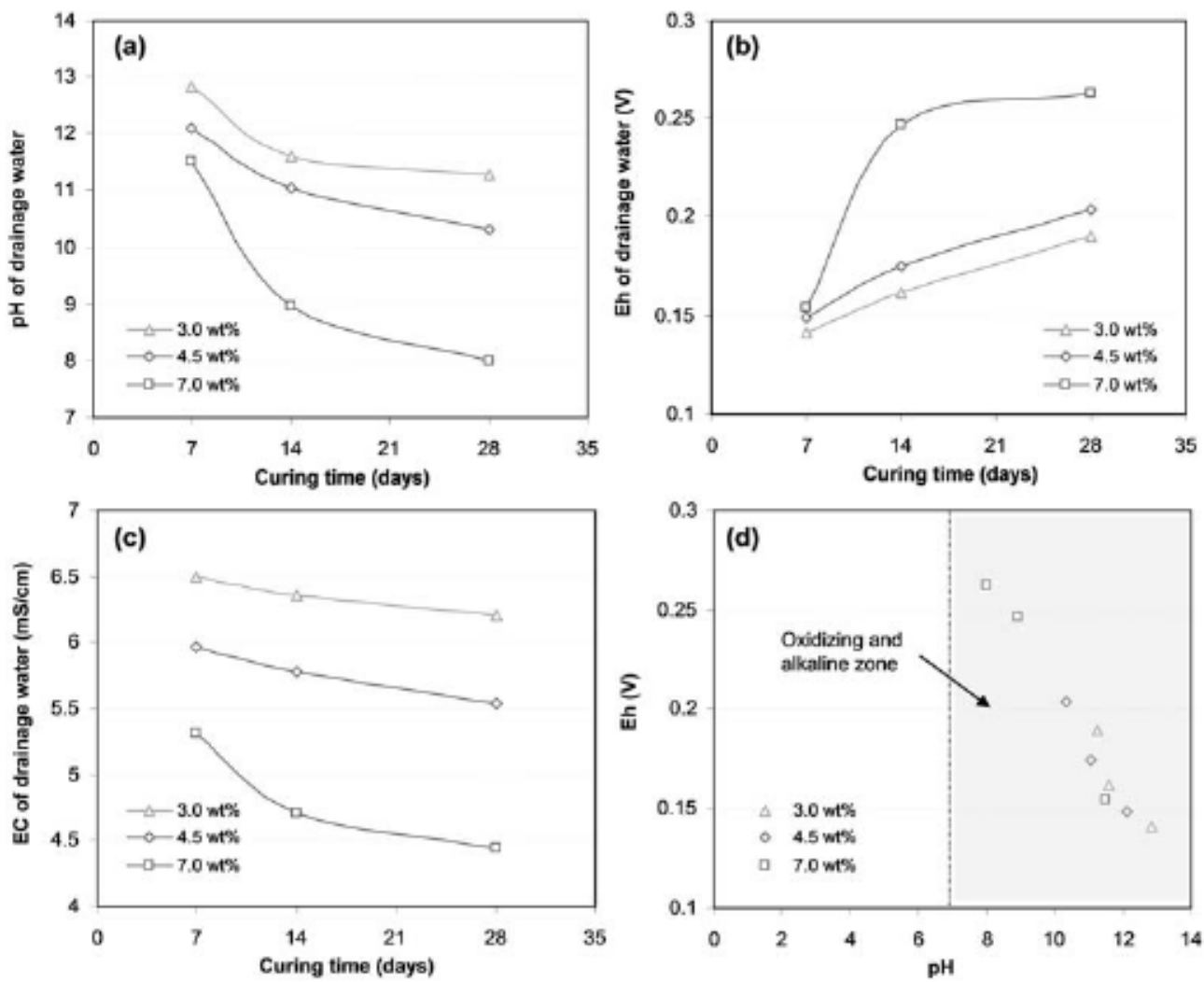

Fig. 8. Geochemical analysis of drainage water

a) $\mathrm{pH}, \mathrm{b}) \mathrm{Eh}, \mathrm{c}) \mathrm{EC}$, and d) $\mathrm{pH}$ vs. Eh

Rys. 8. Analizy geochemiczne wód z odwodnienia

a) $\mathrm{pH}$, b) $\mathrm{Eh}, \mathrm{c}) \mathrm{EC}$, d) $\mathrm{pH}$ vs. $\mathrm{Eh}$ 
For all CPB mixtures, as the amount of binder used in the tailings material sample increases, the $\mathrm{pH}$ and $\mathrm{EC}$ parameter decreases as a function of curing time. However, the Eh value increases with increasing binder content and curing time. In terms of magnitude, the highest $\mathrm{pH}$ change (from 11.5 at 7-day curing to 7.9 at 28 -day curing) is observed for the sample containing $7 \mathrm{wt} \%$ binder content (Fig. 8a). This shows that $\mathrm{pH}$ decreases with increasing binder content and curing time. Besides, the Eh values as shown in Fig. $8 \mathrm{~b}$ indicate that the CUAPS-consolidated sample containing $7 \mathrm{wt} \%$ binder acts differently, while a binder content of both $3 \mathrm{wt} \%$ and $4.5 \mathrm{wt} \%$ act in the same manner. After 7 days of curing, all Eh values are almost the same $(0.141,0.148,0.154$, volts for $3,4.5$, and $7 \mathrm{wt} \%$ binder contents, respectively). In addition, $\mathrm{pH}$ decreases while Eh increases with increased curing time due to the enhanced reactivity of sulphide during the sample preparation and mixing. Oxidation of pyrite accelerates acidity (i.e. the decrease of $\mathrm{pH}$ ) and gives rise to a loss of strength over time. The degree of saturation $S_{r}$ is closely related to the Eh parameter. Eh increases with the decrease in $S_{r}$ which contributes to the increase in oxidation by molecular oxygen diffusing through CPB samples. At the highest binder content (7 wt \%), the $S_{r}$ value is much lower compared to other binder contents (3 and $4.5 \mathrm{wt} \%$ ) and the Eh value becomes higher, as can be seen in Fig. 8b. However, as curing time increases, the gap observed between 7 and $4.5 \mathrm{wt} \%$ binder contents increases from 0.17 to 0.25 after 14 days, and from 0.2 to 0.26 after 28 days. The electrical conductivity EC value decreases from 6.5 to $6.2 \mathrm{mS} / \mathrm{cm}$, from 5.9 to $5.5 \mathrm{mS} / \mathrm{cm}$, and from 5.3 to $4.4 \mathrm{mS} / \mathrm{cm}$ when curing time is increased from 7 to 28 days (Fig. 8c). In addition, the Eh versus pH curve, as indicated in Fig. 8d, shows that the drainage water exhibits an oxidizing and alkaline medium.

\section{Conclusion}

This study compared the results of laboratory testing conducted in order to better understand the hydromechanical and geochemical properties of consolidated (using a new laboratory apparatus called CUAPS) and unconsolidated (using plastic moulds) CPB samples. From the tests performed, one can conclude that the one-dimensional consolidation of CPB samples being cured under a series of pressure increments is essential to a better understanding of events linked to placement and curing conditions occurring in underground stopes during the backfilling process. The CUAPS-consolidated CPBs always give higher mechanical strengths than those obtained from plastic moulds (undrained) for a given binder content and curing time. Geotechnical index parameters show that void ratio is dramatically reduced when CPB samples are prepared using CUAPS cells that allow drainage during a curing time of 7,14, and 28 days. The reduction in the void ratio gives rise to a stiffer, and therefore more resistant, $\mathrm{CPB}$ material. From the chemical composition analysis, it can be noted that the concentrations of sulphate $\mathrm{SO}_{4}{ }^{2-}$ continuously decrease over time, depending on the binder content used in the CPB mixture. Geochemical analyses have also shown that drainage water exhibits an alkaline to neutral oxidizing medium, based on the relationship 
between $\mathrm{pH}$ and $\mathrm{Eh}$. These results showed that the CUAPS apparatus gives higher CPB mechanical strength than UCS values from laboratory-prepared CPB samples. Consequently, more realistic mechanical strength results can be obtained using this new apparatus. More work is underway to validate the values obtained by the CUAPS apparatus and in situ results.

\section{Acknowledgements}

The study was partly granted by the Canada Research Chair on Integrated Management of Sulphide Mine Waste using Mine Fill Technology and the Industrial NSERC-Polytechnique-UQAT Chair on Environment and Mine Wastes Management. The authors would like to express their appreciations to Canadian Foundation for Innovation for the financial support in designing and manufacturing the CUAPS setups. A special thank goes out to URSTM technical staff, chiefly Mélanie Bélanger and Mélinda Gervais for their support on a range of chemical and geochemical analyses.

\section{REFERENCES}

Archibald et al, 1999 - A r ch ibald J.F., Chew J., L au sch P., 1999 - Use of ground waste glass and normal Portland cement mixtures for improving slurry and paste backfill support performance. CIM Bulletin, Vol. 92 , No. 1030, pp. 74-80.

ASTM Designation D2435, 1999 - Standard test method for one-dimensional consolidation properties of soils. Annual Book of ASTM Standards, 04.08, American Society of Testing Material, MD, 207-216.

ASTM Designation D4186, 1999 - Standard test method for one-dimensional consolidation properties of soils using controlled-strain loading. Annual Book of ASTM Standards, 04.08, American Society of Testing Material, Easton, MD, 477-481.

ASTM Designation D806, 1999 - Standard test method for cement content of soil-cement mixtures. Annual Book of ASTM Standards, 04.08, American Society of Testing Material, Easton, MD, 85-87.

ASTM Designation C143, 1999 - Standard test method for slump of hydraulic cement concrete. Annual Book of ASTM Standards, 04.01, American Society of Testing Material, Easton, MD, 68-76.

ASTM Designation C39, 1999 - Standard test method for compressive strength of cylindrical concrete specimens. Annual Book of ASTM Standards, 04.02, American Society of Testing Material, Easton, MD, 15-23.

Belem et al, 2000 - B elem T., Ben zaaz o ua M., Bus sière B., 2000 - Mechanical behaviour of cemented paste backfill. [In:] The 53rd Canadian Geotechnical Conference, September 18-20, Montréal, Quebec, Canada, Canadian Geotechnical Society, pp. 373-380.

Belem et al. 2002 - Belem T., Benzaazoua M., Bussière B., Dagenais A.M., 2002 - Effects of settlement and drainage on strength development within mine paste backfill. [In:] The 9th International Conference on Tailings and Mine Waste, January 27-30, Vail, USA, Balkema: Rotterdam, pp. 139-148.

Belem etal, 2006- B elem T.,El A at ar O., B uss ière B., Benza azou a M., Fall M., Yilmaz E., 2006Characterization of self weight consolidated paste backfill. [In:] The 9th International Seminar on Paste and Thickened Tailings, April 3-7, Limerick, Ireland, ACG, pp. 333-345.

Belem T., B en z a azo ua M., 2008 - Design and application of underground mine paste backfill technology. Geotechnical and Geological Engineering, Vol. 26, No. 2, pp. 147-174.

Benzaazoua et al, 2002 - Benzaazoua M., Belem T., Bussiere B., 2002 - Chemical factors that influence the performance of mine sulphidic paste backfill. Cement and Concrete Research, Vol. 32, No. 7, pp. 1133-1144. 
Benzaazoua et al, 2004 - B enza azo ua M., Fall M., Belem T., 2004 - A contribution to understanding the hardening process of cemented paste backfill. Minerals Engineering, Vol. 17, No. 2, pp. 141-152.

Benzaazoua et al, 2006 - Benzaazoua M., Belem T., Yilmaz E., 2006 - Novel laboratory tool for paste backfill. Canadian Mining Joumal, Vol. 127, No. 3, pp. 31-33.

Bussièr e B, 2007 - Colloquium 2004: Hydrogeotechnical properties of hard rock tailings from metal mines and emerging geoenvironmental disposal approaches. Canadian Geotechnical Journal, Vol. 44, No. 9, pp. 1019-1052,

Cay ou et te J., 2003 - Optimization of the paste backfill plant at Louvicourt mine. CIM Bulletin, Vol. 96, No. 1075, pp. 51-57.

Cihangir et al, 2012 - Cihan gir F., Ercikdi B., Kesimal A., T uran A., Deveci H., 2012 - Utilisation of alkali-activated blast furnace slag in paste backfill of high-sulphide mill tailings: Effect of binder type and dosage. Minerals Engineering, Vol. 30, No. 3, pp. 33-43.

Ercikdi et al. 2010- Ercikdi B., Kesimal A., Cihangir F, Deveci H., Alp I, 2010 -Effect of natural pozzolans as mineral admixture on the performance of cemented-paste backfill of sulphide-rich tailings. Waste Management and Research, Vol, 28, No. 5, pp. 430-435.

Fall M., S am b S., 2008 - Effect of high temperature on strength and microstructural properties of cemented paste backfill, Journal of Fire Safety, Vol. 44, No. 44, pp. 642-665.

Fall et al. 2010 - Fall M., Céles tin J.,P ok harel M., T ou ré M., 2010 - A contribution to understanding the effects of temperature on the mechanical properties of cemented mine backfill. Engineering Geology, Vol, 14, No. 3-4, pp. 397-413.

Fourie et al, 2006 - Fou rie A., Helins ki M., F a hey M., 2006-Filling the gap - a geomechanics perspective. Australian Centre for Geome chanics (ACG) Newsletter, Vol. 26, No. 5, pp. 1-4.

Grab ins ky M., Si mms P., 2006-Self desiccation of cemented paste backfill and implications for mine design. [In:] The 9th International Seminar on Paste and Thickened Tailings, A pril 3-7, Limerick, Ireland, ACG, pp. 323-332.

Hassan i F.P., Bo is D., 1992 - Economic and technical feasibility for backfill design in Quebec underground mines. Final report 1/2, Canada-Quebec Mineral Development Agreement, Research and Development in Quebec Mines. Contract No EADM 1989-1992.

Helinski et al. 2007- Helinski M., F a h ey F.,Four ie A.B., 2007 - Numerical modelling of cemented paste backfill deposition. Joumal of Geotechnical and Geoenvironmental Engineering ASCE, Vol. 13, No. 10, pp. 1308-1319.

Kesimal et al, 2004 - Kesimal A., Yilmaz E., Ercikdi B., 2004 - Evaluation of paste backfill test results obtained from different size slumps with varying cement contents for sulphide-rich tailings. Cement and Concrete Research, Vol. 34, No. 5, pp. 1817-1822.

Kle in K., Simon D., 2006 - Effect of specimen composition on the strength development in cemented paste backfill. Canadian Geotechnical Journal, Vol. 43, No. 3, pp. 310-324.

Landriault D., 2001 - Backfill in underground mining: Underground mining methods engineering fundamentals and international case studies. [In:] Society for Mining Metallurgy and Exploration, Chapter 69, Littleton, Colorado, pp. 601-614.

le Roux et al, 2005 - le Roux K.A., B a wd en W.F., Grabinsk y M.F., 2005 -Field properties of cemented paste backfill at the Golden Giant mine. Mining Technology: IMM Trans. Sec. A, Vol. 114, No. 2, pp.65-80.

Ou ellet S., 2007 - Mineralogical characterization, microstructural evolution and environmental behaviour of mine cemented paste backfills. In PhD Dissertation, University of Quebec at Abitibi-Témiscamingue (UQAT), Rouyn-Noranda, Quebec, Canada, pp. 1-310.

Revell M.B., 2004 - Paste: How strong is it? [In:] The 8th International Symposium on Mining with Backfill, September 19-21, Beijing, China, Metals Society of China, pp. 286-294.

Servant S., 2001 -Détermination des paramètres mécaniques des remblais miniers faits de résidus ciments. [In:] Master's Thesis, McGill University, Montreal, Quebec, pp. 1-53.

Yilmaz E., 2010 - Investigating the consolidation behavior, hydro-mechanical and micro-structural properties of cemented paste backfills using the versatile CUAPS apparatus. [In:] Ph.D. Thesis, Université du Québec en Abitibi-Témiscamingue (UQAT), Québec, Canada, pp. 1-450. 
Yilmaz E., 2011. Advances in reducing large volumes of environmentally harmful mine waste rocks and tailings, Mineral Resources Management, Vol. 27, No. 2, pp. 89-112.

Yilmaz et al, 2008 - Yilmaz E., Belem T., Bussiere B., Benzaazoua M., 2008 - Consolidation characteristics of early age cemented paste backfill. [In:] The 61st Canadian Geotechnical Conference, September 21-24, Edmonton, Alberta, Canada, Canadian Geotechnical Society, pp. 797-804.

Yilmaz et al, 2009 - Yilmaz E., Benza a zoua M., B elem T., B uss iè re B., 2009 -Effect of curing under pressure on compressive strength development of cemented paste backfill. Minerals Engineering, Vol, 22, No. 9-10, pp. 772-785.

Yilmaz et al, 2010 - Yilmaz E., Belem T., B enzaazoua M., Bussière B., 2010 - Assessment of the modified CUAPS apparatus to estimate in situ properties of cemented paste backfill. Geotechnical Testing Joumal, Vol. 33, No. 5, pp. 351-362.

Yilmaz et al. 2012 - Yilmaz E., Belem T., Benzaazou a M., 2012 - One-dimensional consolidation parameter of cemented paste backfills, Mineral Resources Management, Vol. 28, No. 4, pp. 1-18.

Yilmaz et al. 2012 - Yilmaz E., B elem T., Benzaazoua M., Kesimal A., Ercikdi B.,Cihangir F, 2011 - Use of high-density paste backfill for safe disposal of copper/zinc mine tailings. Mineral Resources Management, Vol. 27, No. 3, pp. 81-94.

\section{BADANIA FIZYKOCHEMICZNE I MECHANICZNE WL.AŚCTWOŚC \\ SKONSOUDOWANYCH I NIESKONSOLIDOWANYCH ZA WIESIN NASYCONYCH CEMENTEM}

Słowa kluczowe

Odpady do podsadzki, woda w zrobach, indeks geologiczny, efektywne ciśnienie, siła

\section{Streszczenie}

W ostatnich latach obserwuje się, że wydajność i jakość próbek zawiesin nasyconych cementem (CPB Cement Paste Backfill) in situ są stale niższe niż tych samych próbek przygotowanych w plastikowych formach w laboratorium. Może to wynikać z braku w labora torium skutecznego narzẹdzia mogącego naśladow ać zawiesiny in situ, warunki ich utwardzania jak również rozmiary i geometrię próbek. W celu wypehnienia tej luki, w laboratorium opracowano nowe narzętzie o nazwie CU APS (Curing Under Applied Pressure System), wytworzone i wykorzystane do zbadania wpływu ciśnienia na podstawie skutecznego nacisku na właściwości fizykochemiczne i mechaniczne CPB, jak również próbek otrzymanych z plastikowych form. Badania porównawcze przeprowadzono zarówno dla próbek CUAPS jak i próbek otrzymanych w laboratorium, zawierających lepiszcza (cementu) 3,45 i $7 \%$ wag. po 7, 14 i 28 dniach utwardzania. Wyniki wskazują że wydajność próbek konsolidowanych CUAPS sq zawsze bardziej prawdziwe (realistyczne) niż próbek otrzymanych w laboratorium, głównie z powodu odprowactania wody w wyniku konsolidacji. Ostatecznie metoda CUAPS powoduje korzystny wptyw na utwardzenie CPB dzięki zawartości wody (separacja wody od świeżej zawiesiny odpadów z cementu) i połączeniu części wody zasobowej z zawiesina w zrobach. 
100

\title{
STUDY OF PHYSICO-CHEMICAL AND MECHANICAL CHARACTERISTICS OF CONSOUDATED
} AND UNCONSOLIDATED CEMENTED PASTE BACKFILLS

$$
\text { Key words }
$$

Tailings backfill, drainage water, geological index parameter, effective stress, strength

\begin{abstract}
In recent years, it has been observed that the performance and quality of in situ cemented paste backfill (CPB) samples are constantly lower than samples obtained from the same CPB mix poured into laboratory-prepared plastic moulds. This could be well explained by the absence of an efficient laboratory tool capable of mimicking CPB's in situ placement, hardening, and curing conditions relating to stope size and geometry. To meet this need, a new laboratory tool named CUAPS (curing under applied pressure system) was manufactured and used to examine the effect of curing under effective stress on physico-chemical and mechanical properties of CPB, along with plastic mould samples. A comparative study was conducted for both CUAPS and mould samples containing a binder content of $3,4.5$, and $7 \mathrm{wt} \%$ after curing times of 7,14 , and 28 days. Results indicate that the performance of CUAPS-consolidated samples are always more realistic than those of plastic mould-unconsolidated samples mainly due to water drainage induced by consolidation. CUAPS has witnessed an advantageous effect on CPB hardening which includes the amount of bleeding water (separation of water from the fresh backfill material) and a combination of drainage of part of the mixing water and the settlement of paste backfill after its placement in the cap.
\end{abstract}

